\title{
ANALISIS PERCEPATAN WAKTU DAN BIAYA DENGAN METODE CRASHING PADA PROYEK PEMBANGUNAN BREAKWATER PANGANDARAN
}

\section{ANALYSIS OF TIME AND COST ACCELERATION WITH CRASHING METHOD IN PANGANDARAN BREAKWATER DEVELOPMENT PROJECT}

\author{
Dewi Laras \\ Program Studi S1 Teknik Sipil, Fakultas Teknik dan Sains \\ Universitas Muhammadiyah Purwokerto
}

\section{Informasi Artikel \\ Dikirim, \\ Direvisi, \\ Diterima,}

\section{Korespondensi Penulis:}

Dewi Laras Sulastri Ningsih Program Studi Teknik Sipil Universitas Muhammadiyah Purwokerto JL. K.H. Ahmad Dahlan Purwokerto, 53182

Email:

dewilaras96@gmail.com

\section{ABSTRAK}

Dalam mencapai keberhasilan proyek diperlukan manajemen yang baik dari penjadwalan proyek, penyusunan kegiatan dan hubungan antar kerja yang terperinci dan detail. Dengan tujuan untuk membantu evaluasi proyek dan mengetahui percepatan waktu dengan biaya semaksimal mungkin dalam pelaksanaan proyek pembangunan Breakwater Pangandaran. Metode yang dilakukan untuk analisis ini menggunakan metode crashing dengan bantuan program Primavera Planner, untuk mengetahui waktu pekerjaan yang efektif dan biaya yang efisiensi dengan melakukan percepatan. Dari hasil analisis didapatkan waktu normal 118 hari menajdi 106 hari dengan penambahan waktu lembur 4 jam perhari dan biaya awal proyek sebesar Rp. 16.519915.006,00 menjadi Rp. 16.311.347.006,00.Sehingga mengalami penurunan waktu yang efektif sebesar 10,17\% dengan efisiensi biaya sebesar Rp. 183.676.000,00 untuk proyek pembangunan breakwater Pangandaran.

Kata Kunci : Proyek, Crashing, waktu, biaya

\section{ABSTRACT}

Achieving project success requires good management of project scheduling, detailed and detailed preparation of activities and work relationships. To help project evaluation and know the acceleration of time at the maximum possible cost in the implementation of the Pangandaran Breakwater development project. The method used for this analysis uses the crashing method with the help of the Primavera Planner program, to determine the effective work time and cost efficiency by accelerating. From the results of the analysis, it was found that the normal time from 118 days became 106 days with the addition of 4 hours of overtime per day and the initial project cost of Rp. 16,519915,006.00 to Rp. 16.311.347.006.00. So that the effective time decreased by $10.17 \%$ with a cost efficiency of Rp. 183,676,000.00 for the Pangandaran breakwater construction project.

Keywords: Project, Crashing, time, cost 


\section{PENDAHULUAN}

Pelaksanaan proyek konstruksi merupakan rangkaian dari kegiatan yang saling bergantung satu sama lain. Semakin besar suatu proyek, menyebabkan semakin banyak pula masalah yang harus dihadapi. Mulai dari perencanaan kita dihadapkan pada pengaturan sumber daya seperti tenaga kerja, biaya, waktu, peralatan, dan lain sebagainya, sampai pada pelaksanaan proyek. Jika hal-hal tersebut tidak ditangani dengan benar, berbagai masalah akan muncul seperti keterlambatan penyelesaian proyek, penyimpangan mutu, pembiayaan membengkak, pemborosan sumber daya dan lain sebagainya yang sangat merugikan bagi pelaksanaan proyek [6]. Tolak ukur keberhasilan dalam suatu proyek dapat dilihat dari wakttu penyelesaian yang singkat dengan biaya yang minimal, akan tetapi mutu yang dihasilkan tetap sesuai yang direncanakan. Pengelolaan suatu proyek dilakukan secara sistematis untuk memastikan waktu pelaksanaan sesuai dengan yang direncanakan atau bahkan lebih cepat sehingga memberikan keuntungan pada biaya yang dikeluarkan. Serta, menghindari dari adanya denda akibat keterlambatan penyelesaian proyek [1]. Dalam percepatan waktu setiap kegiatan suatu proyek (crashing project time) dari waktu normalnya, pasti menyebabkan waktu selesainya proyek menjadi lebih cepat. Tetapi percepatan waktu kegiatan-kegiatan ini juga akan mempengaruhi proyek segi biaya khususnya untuk setiap kegiatan yang waktunya dipercepat, menjadi lebih tinggi, sehingga secara total biaya proyek menjadi lebih besar dari pada biaya normalnya [2]. Untuk melakukan percepatan ada beberapa alternatif misalnya, penambahan jam kerja dan penambahan tenaga kerja.

Ada beberapa Ada beberapa yang menjadi kendalam percepatan penyelsaian waktu proyek diantaranya :

- Jumlah tenaga kerja yang tersedia

- Jumlah peralatan yang tersedia

- Persyaratan mutu produk yang dihasilkan

- Pasokan material

- Dana yang tersedia

- Kendala non teknis

Dalam analisis waktu dan biaya dalam proyek konstruksi merupakan suatu proses perhitungan waktu dan biaya yang diperlukan untuk memulai sampai mengakhiri suatu pekerjaan proyek. Pada kondisi optimal, faktorfaktor biaya, waktu, dan kuantitas membentuk tata hubungan yang saling bergantung serta berpengaruh kuat dengan kepekaan tinggi. Kemudian dikembangkan darinya, jadwal rencana kerja utama yang dilengkapi dengan rambu-rambu marka atau titik kontrol dan jadwal rencana anggaran pembiayaan [3].

Salah satunya pada proyek pembangunan breakwater Pangandaran, untuk menghindari adanya keterlambatan dalam proyek maka dilakukan penelitian percepatan waktu dan biaya dengan metode crashing. Pembangunan breakwater di Pangandaran ini fungsinya sebagai pengamanan pantai penahan arus ombak laut dan untuk mengembalikan fungsi pengaman pantai sebagai salah satu konservasi sumber daya air serta melakukan pengamanan pantai dalam upaya meningkatkan pengaman sebagai ruang publik yang dapat dimanfaatkan masyarakat [4].

Dengan tujuan dari penelitian ini untuk mengetahui waktu yang efektif dan efektifitas waktu yang optimal dari pembangunan breakwater Pangandaran. Dan mengetahui biaya yang paling efisien untuk proyek pembangunan breakwater Pangandaran. Dengan menganalisis waktu dan biaya nya dengan metode crashing.

\section{METODE PENELITIAN}

\subsection{Lokasi dan Metode Pengumpulan Data}

Lokasi penelitian berada di kawasan pantai dan perairan sisi barat pantai Pangandaran, Kabupaten Pangandaran, Provinsi Jawa Barat dengan letak area pekerjaan pembangunan Breakwater dengan jarak 250 meter dari bibir pantai [4]. Penelitian ini menggunakan data sekunder dari intasi dan dinas yang terdiri dari data Rencana Anggaran Biaya (RAB), jadwal proyek (time scheddule) dan laporan kemajuan proyek. Di bawah ini merupakan lokasi untuk pembuatan Breakwater di Pangandaran.

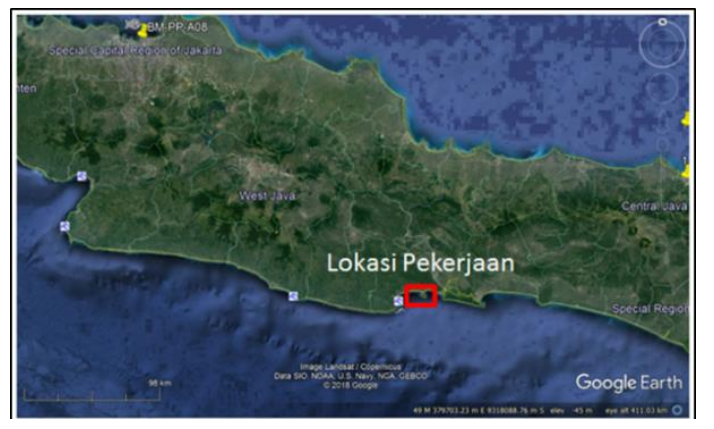

CIVeng Vol.2, No.2, Juli 2021 : 87 94 


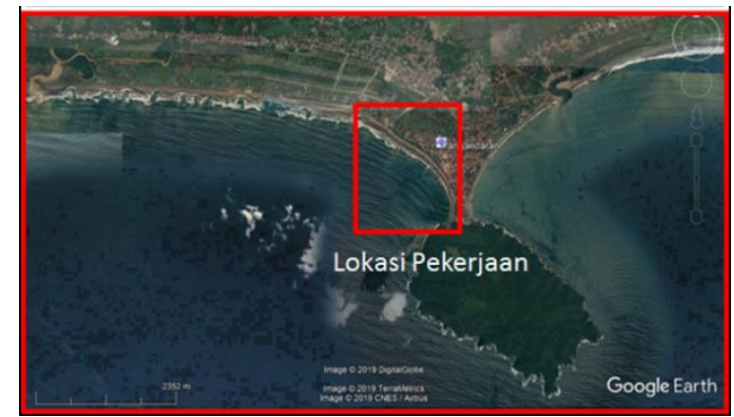

Gambar 1. Lokasi Pembangunan Breakwater Pangandaran

\subsection{Perhitungan metode crashing}

Metode yang digunakan dalam penelitian ini menggunakan metode crashing dengan bantuan program primavera planer. Proses crashing dilakukan agar pekerjaan selesai dengan pertukaran silang waktu dan biaya dengan menambah jumlah jam kerja, jumlah tenaga kerja, jumlah ketersediaan bahan, serta memakai peralatan yang lebih produktif dan metode instalasi yang lebih cepat sebagai komponen biaya direct cost [5]. Dalam metode crashing akan dibagi menjadi dua untuk perhitungan percepatan waktu dan analisis biaya. Selanjutnya akan mengidentifikasi jalur kritis (critical path) pada program Primavera Planner untuk mengetahui waktu yang efketif dan biaya yang efisien untuk menganalisisnya.

\subsubsection{Perhitungan percepatan waktu (crash duration)}

Produktivitas harian dimana volume pekerjaan dibagi dengan durasi/waktu normal

$$
X=\frac{\text { Volume }}{\text { Durasi normal }}
$$

Produktivitas tiap jam dimana produktivitas harian dibagi jam kerja perharinya

Produktivitas harian sesudah crash

$$
Y=\frac{\text { Produktivitas harian }}{\text { Jam kerja perhari }}
$$

Keterangann :

$$
\mathrm{Z}=(\text { Jam kerja perhari } \mathrm{x} \text { Produktivitas tiap jam })+(\mathrm{a} \times \mathrm{b} \text { x Produktivitas tiap jam })
$$

a : lama penambahan jam lembur

$\mathrm{b}$ : koefisien penurunan produktivitas akibat penambahan jam lembur

percepatan waktu (crash duration) dimana volume pekerjaan dibagi dengan produktifitas harian yang sudah di percepat

$$
\text { Crash Duration }=\frac{\text { Volume }}{\text { Produktivvitas harian sesudah crash }}
$$

\subsubsection{Perhitungan analisis biaya}

Untuk perhitungan biaya yang terdiri dari biaya langsung, biaya tidak langsung dan biaya lain-lain. Dimana dalam perhitungan biaya ini melakukan biaya optimasi dengan penambahan tenaga kerja dan jam kerja (lembur) dalam mempercepat waktu.

Kebutuhan tenaga kerja perhari lembur

Upah tenaga kerja lembur

$$
\mathrm{a}=\frac{(\text { Koefisien tenaga kerja } \times \text { volume })}{\text { Durasi Crash }}
$$

Total upah tenaga kerja lembur

$$
\mathrm{b}=\text { Jumlah tenga kerja perhari } \mathrm{x} \text { Upah harian pekerjaan }
$$

$$
\mathrm{c}=\sum \text { Upah per hari } \mathrm{x} \text { Durasi Crash }
$$

\subsubsection{Mengidentifikasi lintasan kritis (critical path) pada jaringan kerja}

Untuk mengetahui lintasan kritis merupakan hubungan antara pekerjaan satu dengan pekerjaan lainnya yang saling berhubungan dan dibantu dengan program Primavera Planner sehingga mengetahui durasi proyek dan pekerjaan mana saja yang berada pada jalur kritis. Karena pekerjaan yang masuk dalam jalur kritis dapat melakukan perubahan atau percepatan dalam pelaksnaan proyek tersebut. 


\section{HASIL DAN PEMBAHASAN}

\subsection{Gambaran umum pembangunan breakwater pangandaran}

Untuk pelaksanaan pembangunan break Breakwater Pangandaran ini dilaksanakan pada tahun 2020, diperoleh data-data sebagai berikut :

Nama Proyek : Pengamanan Pantai Pangandaran

Pemilik Proyek : Dinas Pengelolaan Sumber Daya Air Jawa Barat

Lokasi Proyek : Pantai Barat Pangandaran Jawa Barat

Nilai kontrak : \pm Rp. 18.000.000.000,-

Panjang : : $132 \mathrm{~m}$

Masa Pelaksanaan : 161 hari

Masa Pemeliharaan : 160 hari

Tahun Anggaran : 2020

\subsection{Rekapitulasi waktu}

Waktu atau durasi penyelesaian Pembangunan Breakwater Pangandaran yang direncanakan adalah 20 minggu. Dimana dalam 1 minggu terdapat terdapat 6 hari kerja. Durasi masing-masing kelompok pekerjaan dapat dilihat pada tabel 1 . berikut.

Tabel 1. Rekapitulasi Waktu Proyek Pembangunan Breakwater Pangandaran

\begin{tabular}{clc}
\hline No. & \multicolumn{1}{c}{ Uraian } & Durasi (Minggu) \\
\hline \multicolumn{3}{c}{ Proyek Pembangunan Breakwater Pangandaran } \\
\hline 1 & Pekerjaan Persiapan & 20 \\
2 & Tes dan Monitoring & 16 \\
3 & Produksi Unit Armor & 19 \\
4 & Pekerjaan Submerged Breakwater & 18 \\
\hline Sumber:Hasil Analisis,2020
\end{tabular}

\subsection{Rekapitulasi biaya}

Berdasarkan data-data proyek pembangunan Breakwater, terdapat 4 kelompok pekerjaan yang nantinya akan dikembangkan menjadi beberapa sub pekerjaan sesuai dengan kelompok pekerjaan tersebut.

Perincian kelompok pekerjaan dengan masing-masing anggaran biaya dapat dilihat pada Tabel 2. dibawah ini. Untuk lebih jelasnya dapat dilihat pada lampiran.

Tabel 2. Rekapitulasi Biaya Proyek Pembangunan Breakwater

\begin{tabular}{clr}
\hline No. & \multicolumn{1}{c}{ Deskripsi } & \multicolumn{1}{c}{ Total (Rp.) } \\
\hline I & Pekerjaan Persiapan & $465.694 .590,00$ \\
II & Tes dan Monitoring & $12.000 .000,00$ \\
III & Produksi Unit Armor & $13.329 .913 .600,00$ \\
IV & Pekerjaan Submerged Breakwater & $2.265 .477 .816,00$ \\
A. Total & $16.519 .915 .006,00$ \\
B. PPN 10\% & $1.651 .991 .500,60$ \\
C. Total + PPN 10\% & $18.171 .906 .506,60$ \\
\hline Sumber $:$ Dinas PSDA 2020
\end{tabular}

\subsection{Analisis metode crashing}

\subsubsection{Lintasan kritis pada Pembangunan breakwater}

Pada Proyek Pembangunan Breakwater, jalur kritis ini yang diperoleh dari permodelan Primavera Project Planner (P6) dapat dilihat pada Tabel 3.

Tabel 3. Pekerjaan Jalur Kritis

\begin{tabular}{cl}
\hline No & \multicolumn{1}{c}{ Uraian Pekerjaan } \\
\hline 1 & Mobilisasi dan Demobilasi Awal \\
2 & Penerangan, Keamanan dan Keselamatan \\
3 & Fasilitas Sementara \\
4 & Pembuatan Kubus 1x1x1 \\
5 & Pembuatan A-jack 9 ton \\
6 & Pemasangan Geotextil \\
7 & Pemasangan Kubus 1x1x1
\end{tabular}

CIVeng Vol.2, No.2, Juli 2021 : 87 94 
8 Pemasangan Kubus $2 \times 1,5 \times 2$

\subsubsection{Analisis percepatan waktu}

Dalam penelitian ini percepatan waktu dengan metode crashing, sehingga durasi pekerjaan yang berada di jalur kritis dapat mengurangi waktu dengan penambahan jam lembur 4 jam/hari yang dapat dilihat pada tabel 4 . di bawah ini.

Tabel 4. Pekerjaan Crashing

\begin{tabular}{lcccc}
\hline \multicolumn{1}{c}{ Uraian Kegiatan } & Volume (V) & Satuan & $\begin{array}{c}\text { Durasi } \\
\text { Normal } \\
\text { (ND) }\end{array}$ & $\begin{array}{c}\text { Crash } \\
\text { Duration (CD) }\end{array}$ \\
\hline Mobilisasi dan Demobilisasi & 1,00 & LS & 12 & 9 \\
Penerangan, Keamanan dan Keselematan & 1,00 & LS & 138 & 106 \\
Fasilitas Sementara & 1,00 & LS & 138 & 106 \\
Pembuatan Kubus 1x1x1 & $1.628,00$ & Unit & 114 & 88 \\
Pembuatan A-jack 9 ton & 249,00 & Unit & 114 & 88 \\
Pemasangan Geotextil & $2.285,21$ & M $^{2}$ & 36 & 28 \\
Pemasangan Kubus 1x1x1 & $1.628,00$ & Unit & 102 & 78 \\
Pemasangan Kubus 2x1,5x2 & 880,00 & Unit & 102 & 78 \\
\hline
\end{tabular}

Sumber: Analisis, 2020

Setelah dilakukannya Crashing pada beberapa pekerjaan yang berada di jalur kritis, maka didapat total durasi sebelum Crashing yakni 118 hari menjadi 106 hari yang berarti memiliki Crash Duration 12 hari. Berikut adalah Barchart dari percepatan Crashing.

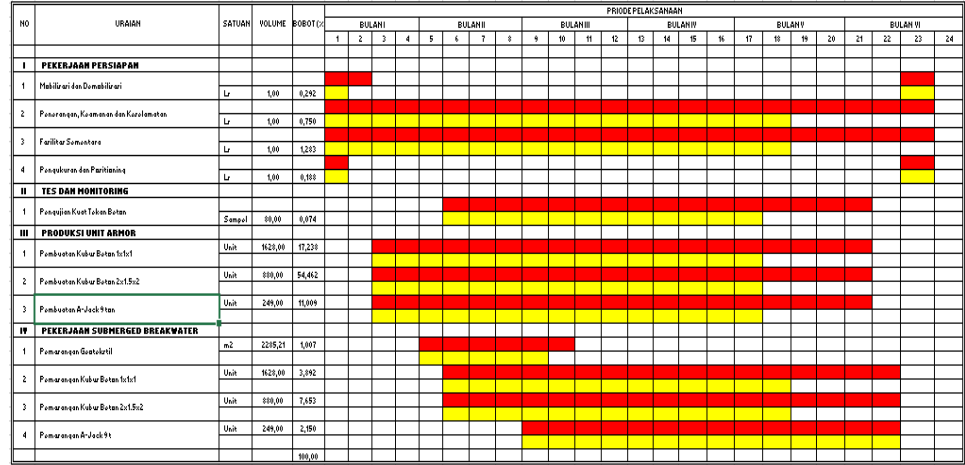

Gambar 2. Barchart Metode Crashing

Keterangan :

Rencana Kegiatan :

Rencana Kegiatan Crashing

\subsubsection{Analisis biaya percepatan}

Untuk penelitian ini dalam perhitungan biaya langsung, tidak langsung, biaya penambahan jam lembur dan biaya lain-lain. Berikut Tabel 5. untuk perhitungan biaya lembur 4 jam/hari pada kegiatan jalur kritis.

\begin{tabular}{lccrrr}
\multicolumn{6}{c}{ Tabel 5. Rekapitulasi Upah Lembur } \\
\hline Uraian Pekerjaan & Volume & Koef. & $\begin{array}{l}\text { Upah } \\
\text { Kerja Lembur }\end{array}$ & $\begin{array}{l}\text { Total } \\
\text { Tenaga } \\
\text { KerjaLembur }\end{array}$ \\
\hline Pengukuran dan Positioning & 1 & 42 & $800.000,00$ & $4.000 .000,00$ \\
Pembuatan Kubus 1x1x1 & 1628 & 0,4 & $1.066 .800,00$ & $93.878 .400,00$ \\
Pembuatan Kubus 2x1,5x2 & 880 & 0,4 & $609.600,00$ & $53.644 .800,00$ \\
Pembuatan A-jack 9 ton & 249 & 0,4 & $152.400,00$ & $13.411 .200,00$ \\
Pemasangan Geotextil & $2.285,21$ & 0,16 & $6.531 .200,00$ & $182.873 .600,00$ \\
Pemasangan Kubus 1x1x1 & 1628 & 0,52 & $5.526 .400,00$ & $431.059 .200,00$
\end{tabular}

Analisis Percepatan Waktu dan Biaya dengan Metode Crashing pada Proyek Pembangunan Breakwater Pangandaran (Dewi Laras) 


\begin{tabular}{crrrr}
$\begin{array}{c}\text { Pemasangan Kubus 2x1,5x2 } 880 \\
\text { Jumlah }\end{array}$ & & 0,52 & $3.014 .400,00$ & $235.123 .200,00$ \\
Sumber : Analisis, 2020 & & $1.013 .990 .400,00$ \\
\hline
\end{tabular}

Dari analisis perhitungan percepatan biaya, didapat rekapitulasi biaya langsung, tidak langsung dan biaya lain-lain. Dapat dilihat pada tabel 6. di bawah ini.

Tabel 6. Total Biaya Dari Metode Crashung

\begin{tabular}{clrr}
\hline \multirow{2}{*}{ No } & \multicolumn{1}{c}{ Kegiatan } & $\begin{array}{c}\text { Durasi Awal } \\
\mathbf{1 1 8} \text { hari }\end{array}$ & $\begin{array}{c}\text { Metode Crashing 106 } \\
\text { Hari }\end{array}$ \\
\hline $\mathbf{1}$ & Biaya Langsung Proyek & $8.853 .031 .406,00$ & $8.853 .031 .406,00$ \\
& Biaya Sewa Alat & $7.220 .054 .600,00$ & $6.030 .762 .200,00$ \\
& Biaya Lembur & - & $1.013 .990 .400,00$ \\
$\mathbf{2}$ & Biaya Tidak Langsung & & \\
& Biaya Gaji Pegawai & $271.400 .000,00$ & $240.720 .000,00$ \\
& Biaya Keamanan & $7.729 .000,00$ & $6.943 .000,00$ \\
& Biaya Lain-lain & $167.700 .000,00$ & $165.900 .000,00$ \\
& Jumlah & $16.519 .915 .006,00$ & $16.311 .347 .006,00$ \\
\hline Sumber : Analisis, 2020 & &
\end{tabular}

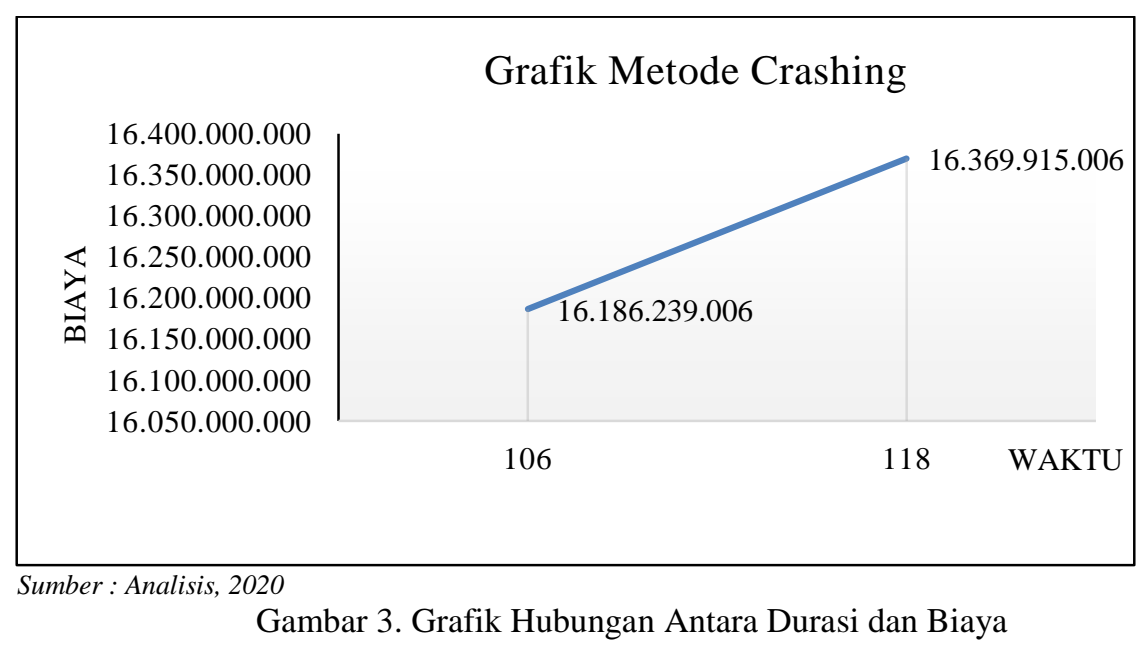

Dapat dilihat dari hasil perhitungan metode crashing pada proyek pembangunan breakwater Pangandaran dari waktu normal 118 hari setelah melakukan percepatan waktu menjadi 106 hari dengan biaya awal proyek Rp. 16.519915.006,00 menjadi Rp. 16.311.347.006,00 dengan penambahan biaya lembur. Sehingga mengalami penurunan sebesar 10,17\% dengan efisiensi biaya sebesar Rp. 183.676.000,00. Dijelaskan dalam grafik diatas hubungan antara lamanya durasi proyek dengan biaya proyek. Sehingga dapat diketahui berapa durasi yang lebih efektif dan berapa biaya yang lebih efisien dari metode percepatan yang telah di analisa.

\section{KESIMPULAN}

Berdasarkan pembahasan dan analisis seperti yang telah diuraikan, maka dapat disimpulkan bahwa berdasarkan data RAB dan Time Schedule dari pekerjaan pembangunan breakwater Pangandaran dengan waktu 118 hari kerja yang didapatkan dari program Primavera Planner. Didapatkan beberapa pekerjaan yang kritis atau lintasan kritis, sehingga melakukan pecepatan waktu dengan metode Crashing dengan penambahan jam lembur kerja 4 jam perhari dan penambahan tenaga kerja maka waktu kerja menjadi 106 hari kerja. Dan biaya awal pekerjaan Rp. 16.519915.006,00 setelah penambahan jam lembur kerja dan penambahan kerja, maka biaya setelah proses crashing menjadi Rp. 16.311.347.006,00 dengan selisih penurunan 10,17\% dengan waktu efektif menjadi 12 hari dan biaya yang efisien sebesar Rp. 183.676.000,00. Sehingga untuk proyek pemabngunan breakwater Pangandaran dapat memiliki durasi yang efektif dan biaya menjadi efisien dari metode percepatan.

\section{DAFTAR PUSTAKA}

[1] M. Priyo, M.R.A.Paridi, " Studi Optimasi Waktu dan Biaya dengan Metode Time Cost Trade Off pada Proyek Konstruksi Pembangunan Gedung Olah Raga (Gor)," Jurnal Ilmiah Teknika, Vol. 21, No. 1, 72-84, 2018. 
[2] Dwijono, D., “ Optimalisasi Waktu Percepatan dan Biaya Kegiatan di dalam Metode Jalur Kritis dengan Pemrograman Linier,” Jurnal Terapan Teknologi Informatika, 1(1), pp. 1-9, 2017.

[3] Dipohusodo, Istimawan, "Manajemen Proyek \& Konstruksi," Kanisius, Jogjakarta, 1996.

[4] Dinas PSDA, "Pengamanan Pantai Pangandaran,” PSDA, Provinsi Jawa Barat, 2020.

[5] Husen, Abrar, "Manajemen Proyek (Perencanaan Penjadwalan dan Pengendalian Proyek)," Penerbit: Andi, Yogyakarta, 2009.

[6] Michael, Kareth, "Analisis Optimalisasi Waktu Dan Biaya Dengan Program Primavera 6.0 (Studi Kasus : Proyek Perumahan Puri Kelapa Gading),” Jurnal Sipil Statik, Vol.1 No. 1, pp. (53-59), 2012. 
